\title{
USE OF LOW-INTENSITY LASER IRRADIATION IN IMPLANT DENTISTRY
}

\author{
Hristina Lalabonova \\ Department of Maxillofacial Surgery \\ Faculty of Dentistry, Medical University, Plovdiv, Bulgaria
}

\begin{abstract}
The stability of dental implants is of great significance for successful osseointegration. The long-term retention of implants, however, depends on how strongly the epithelial and connective tissues adhere to its titanium surface, that is, on how efficiently the soft tissues seal the bone protecting it from the oral bacterial flora. The aim of the present study was to develop a technique that uses low-intensity laser irradiation to stimulate the growth of healthy peri-implant mucosa. The study yielded very good results.
\end{abstract}

Key words: low-intensity laser, dental implants, osseointegration

\section{INTRODUCTION}

Teeth are the only body organs that penetrate the surface epithelium. In this respect, teeth and dental implants are two examples of structures that go through the outermost layer of the human body. For an implant to be properly osseointegrated it needs to be stable, but its survival rate depends largely on how strongly the epithelial and connective tissues adhere to its titanium surface - the stronger the adherence the better the soft tissues seal the bone from the oral bacterial flora. $(5,6,8)$

As far as epithelial structures and components of connective tissue are concerned the gingiva and the periimplant mucosa have a similar structure. It is, however, the absence of root cement layer on the implant's surface that constitute the principal difference between implants and teeth with respect of the orientation of the connective tissue fibres. $(3,11)$

What significance the soft tissue seal around the titanium abutment has for a successful implantation is still a poorly studied problem. Studies have established that the difference in the structure and composition of peri-implant mucosa and periodontal gingiva is as follows: - the gingival supracrestal connective tissue is about $1 \mathrm{~mm}$ high at the places in which the bundles of collagen fibres become fan-like, the cell-free root cement being in the centre. In titanium implants there is no root cement and the bundles of the collagen fibres in the peri-implant mucosa run parallel to the surface of the implant and emerge on the bone surface. The peri-implant supracrestal connective tissue is approximately $2 \mathrm{~mm}$ high. The proliferation capacity of the connective tissue is restricted within this epithelium-free area. This affects the bond between the peri-implant mucosa and the titanium abutment and hence affects the protective capacities of the soft tissue against exogenic stimulation. The peri-implant mucosa contains considerably more collagen and fewer fibroblasts than the respective parts of the gingival connective tissue. $(2,9,10$, 11)

The differences between the gingiva and the periimplant mucosa are in the orientation of the collagen fibres, the high collagen content and the small number of fibroblasts. The peri-implant mucosa is actually very much like cicatricial tissue which leads to impaired defence against exogenic stimuli. It is very important that we create such soft tissues around the implants so that they can form a healthy soft tissue barrier. $(1,7,4)$

The aim of the study was to develop a technique to stimulate the growth of healthy peri-implant mucosa using low-intensity laser irradiation.

Therapeutic protocol:

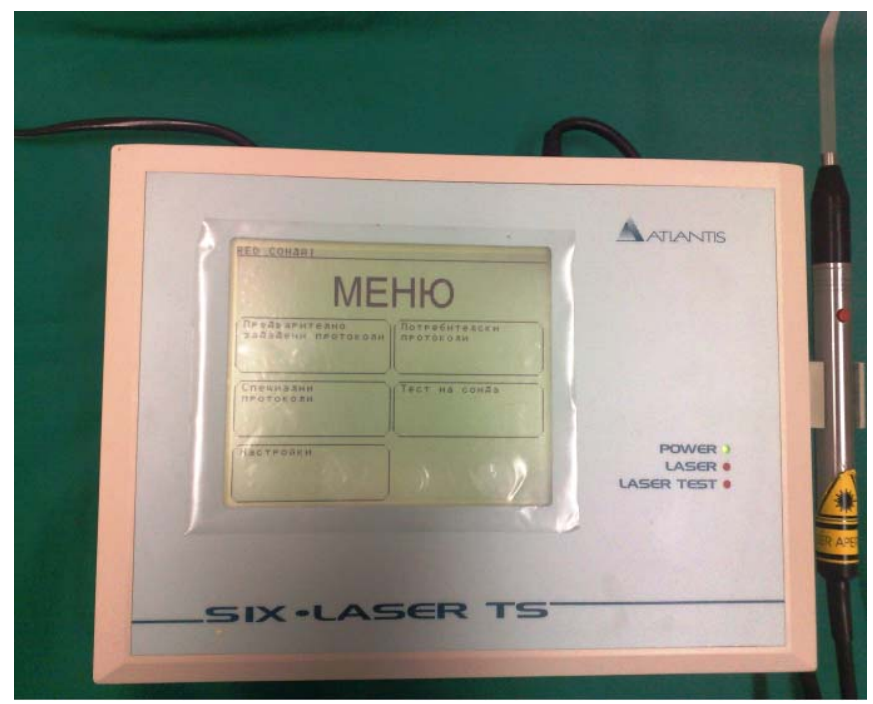

Fig. 1. Red-light laser 


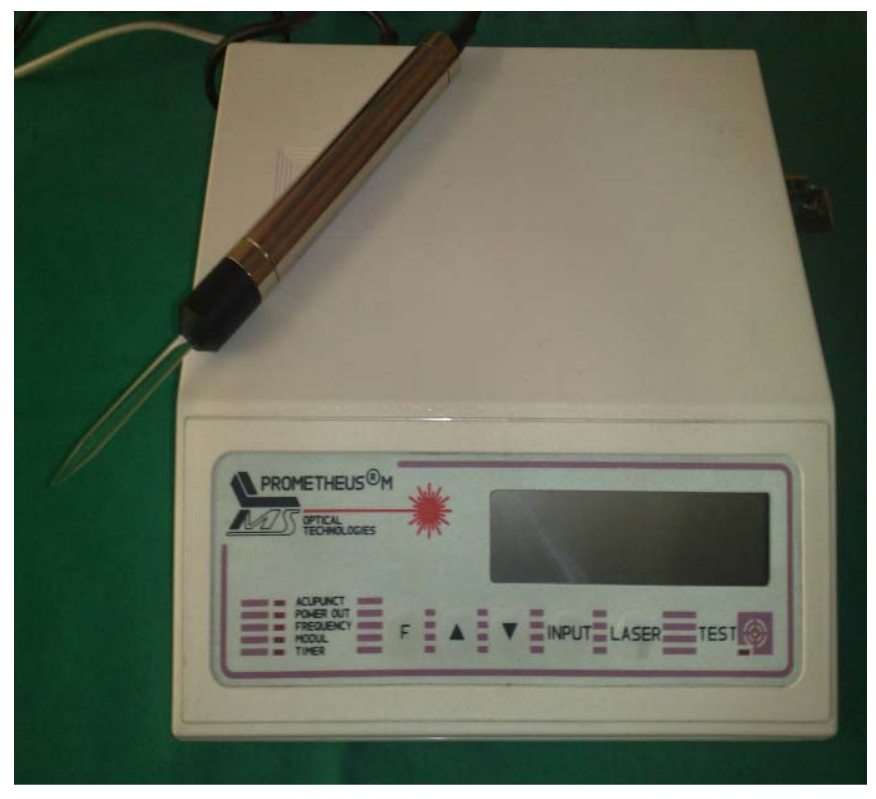

Fig. 2. Infrared-light laser

\section{Prior to implantation}

We use a red-light laser $(\lambda=658 \mathrm{~nm})$ (Fig. 1)

Number of session: 4 daily

Irradiated area: the mucosa in the vicinity of implant sites (Fig. 3)

Size of area $-0.5 \mathrm{~cm}^{2}$ using an optic fibre

Parameters: - power: $27 \mathrm{~mW}$

- dose: $2 \mathrm{~J} / \mathrm{cm}^{2}$

- mode of work: $5 \mathrm{~Hz}+\mathrm{CW}$

- time: $1.14 \mathrm{~min}$.

\section{After placing the implants}

A red-light laser $(\lambda=658 \mathrm{~nm})$ (Fig.1) and an infraredlight laser $(\lambda=904 \mathrm{~nm})$ (Fig.2) are alternated.
Total number of sessions: 5 , distributed as follows:

Number of sessions: $2(\lambda=658 \mathrm{~nm})$ in the red light spectrum

$3(\lambda=904 \mathrm{~nm})$ in the infrared light spectrum

Irradiation starts 4 days after implantation.

Area of irradiation: the mucosa vestibularly and lingually (palatinally) of the implant (Fig.3)

Size of area: $0.5 \mathrm{~cm}^{2}$ using an optic fibre

Parameters: - power: $27 \mathrm{~mW}$

- dose: $2 \mathrm{~J} / \mathrm{cm} 2$

- mode of work: $5 \mathrm{~Hz}+\mathrm{CW}$

- time: $1.14 \mathrm{~min}$.

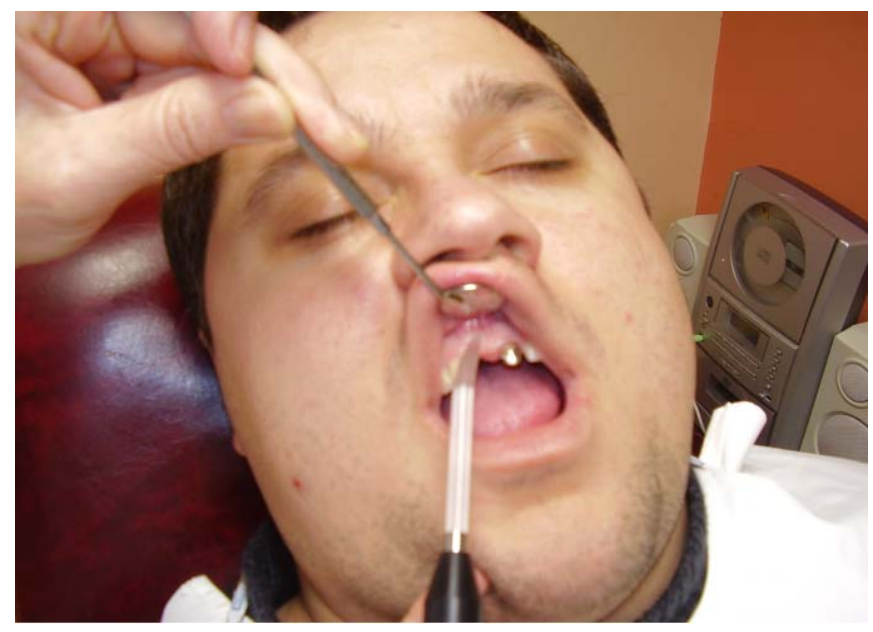

Fig. 3. Technique

\section{CONCLUSION:}

The low-intensity laser irradiation used in the surgical procedures of implant dentistry proved to be efficient. The peri-implant soft tissue became light pink and showed no evidence of inflammation processes The low-intensity laser therapy stimulates the growth of healthy peri-implant mucosa.

\section{REFERENCES:}

1. Каменова Ю. Ниско-енергийна лазерна терапия - интраорални методи и техники. Стоматологична практика, София, 2004, 3, 3-10. (in Bulgarian)

2. Симеонова Р. Клинично проучване върху биостимулиращия ефект на нискоинтензивното лазерно лъчение при труднозарастващи рани. Дисертация, МУ - МФ - Пловдив, 2007. (in Bulgarian)

3. Узунов Ц. Експериментални и клинични изследвания за влиянието на хелий-неоновия лазер при хроничен пародонтит. Дисертация, МУ-ФДМСофия, 2000 г. (in Bulgarian)

4. Pinheiro AL., Cavalcanti ET,
Pinheiro TI, Alves MJ, Manzi CT. Lowlevel laser therapy in the menagment of disorders of maxillofacial region., J Clin Laser Med Surg; 1997;15(4);181-3. [PubMed]

5. Guzzardella GA, Torricelli P, NicoliAldini N, Giardino R. Osseointegration of endosseous ceramic implants after postoperative low-power laser stimulation: an in vivo comparative study. Clin Oral Implants Res. 2003 Apr;14(2):226-232. CrossRef doi: $10.1034 / \mathrm{j} .1600$ 0501.2003.00872.x ] [PubMed ]

6. Khadra M, Rwnold HJ, Lyngstadaas SP, Ellingsen JE, Haanaes HR. Low-level laser therapy stimulates bone-implant interaction: an experimental study in rabbits. Clin Oral Implants Res. 2004 Jun;15(3):325-332. [CrossRef doi: 10.1111/j.1600-0501.2004.00994.x] [PubMed]

7. Khadra M. The effect of low level laser irradiation on implant-tissue interaction. In vivo and in vitro studies. Swed Dent J Suppl. 2005;(172):1-63. [PubMed]

8. Kim YD, Kim SS, Hwang DS, Kim SG, Kwon YH, Shin SH, et al. Effect of low-level laser treatment after installation of dental titanium implant-immunohisto- 
chemical study of RANKL, RANK, OPG: an experimental study in rats. Lasers Surg Med. 2007 Jun;39(5):441-450. [CrossRef doi: 10.1002/lsm.20508] [PubMed]

9. Lopes CB, Pinheiro AL, Sathaiah S, Duarte J, Cristinamartins M. Infrared laser light reduces loading time of dental implants: a Raman spectroscopic study.
Photomed Laser Surg. 2005 Feb;23(1):2731. DOI: 10.1089/pho.2005.23.27 CrossRef] [PubMed]

10. Lopes CB, Pinheiro AL, Sathaiah S, Da Silva NS, Salgado MA. Infrared laser photobiomodulation (lambda $830 \mathrm{~nm}$ ) on bone tissue around dental implants: a Raman spectroscopy and scanning electronic microscopy study in rabbits. Photomed Laser Surg. 2007 Apr;25(2):96101.[CrossRefdoi:10.1089/pho.2006.2030] [PubMed]

11. Palacci P, Ericsson I, Engstrand P, Rangert B. Optimal Implant Positioning \& Soft Tissue Menagement for Brenemark System. Quintessence Co, 1995. 85p.

Address for correspondence:

Assoc. prof. Hristina Lalabonova

Department of Maxillofacial Surgery

Faculty of Dentistry, Medical University, Plovdiv

11 Opalchenska Str., 4000 Plovdiv, Bulgaria

Tel.: +359888608 406

E-mail: lalabonova@abv.bg 